\title{
INTERNATIONAL MACROECONOMICS
}




\section{INTERNATIONAL \\ MACROECONOMICS}

\section{Emmanuel Pikoulakis}

with contributions from

Frederick van der Ploeg

and

Ronald MacDonald

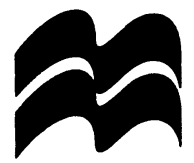


All rights reserved. No reproduction, copy or transmission of this publication may be made without written permission.

No paragraph of this publication may be reproduced, copied or transmitted save with written permission or in accordance with the provisions of the Copyright, Designs and Patents Act 1988, or under the terms of any licence permitting limited copying issued by the Copyright Licensing Agency, 90 Tottenham Court Road, London W1P 9HE.

Any person who does any unauthorised act in relation to this publication may be liable to criminal prosecution and civil claims to damages.

First published 1995 by

MACMILLAN PRESS LTD

Houndmills, Basingstoke, Hampshire RG21 2XS

and London

Companies and representatives

throughout the world

ISBN 978-0-333-59896-2 ISBN 978-1-349-24295-5 (eBook)

DOI 10.1007/978-1-349-24295-5

A catalogue record for this book is available from the British Library.

$\begin{array}{rrrrrrrrrr}10 & 9 & 8 & 7 & 6 & 5 & 4 & 3 & 2 & 1 \\ 04 & 03 & 02 & 01 & 00 & 99 & 98 & 97 & 96 & 95\end{array}$


To the memory of my parents 


\section{Contents}

List of Tables and Figures

Acknowledgements

$\mathbf{X}$

xiii

Introduction

1 Approaches to the Balance of Payments and the Exchange Rate: The Case of Capital Immobility

1.1 Introduction 5

1.2 The accounting framework of the balance of payments 6

1.3 The elasticities approach to the balance of payments and the exchange rate

1.4 The absorption approach to the balance of payments and the exchange rate

1.5 The monetary approach to the balance of payments and the exchange rate

2 The Asset Approach to the Exchange Rate: Monetary

Models of the Exchange Rate

2.1 Introduction

2.2 Monetary models of the exchange rate: the case of flexible prices

2.3 Monetary models of the exchange rate: full employment and sticky prices

2.4 Monetary models of the exchange rate: demand-determined outputs and sticky prices

2.5 Concluding remarks

3 The Asset Approach to the Exchange Rate: Portfolio

Balance Models of the Exchange Rate and the Current Account

3.1 Introduction

3.2 A mean-variance analysis of portfolio choice

3.3 Monetary policy, expectations and the exchange rate

3.4 Monetary policy and the degree of asset substitution 
3.5 The exchange rate, the current account and expectations

3.6 Responses of the exchange rate and the current account to sterilised and non-sterilised, unanticipated, open-market operations

3.7 Concluding remarks

4 Exchange Rates, Expectations and the Current Account

4.1 Introduction

4.2 A description of the model: setting the agenda

4.3 Short-run equilibrium responses under exogenous expectations

4.4 Impact, dynamic and steady-state adjustments under static expectations

4.5 The nominal exchange rate and the current account under perfect foresight

4.6 Concluding remarks

5 The Cost of Disinflation in a Floating Exchange Rate Regime

5.1 Introduction

5.2 The basic Buiter-Miller model

5.3 The cost of disinflation when non-sterilised intervention takes place

5.4 Conclusion

6 The Exchange Rate and the Current Account when Prices Evolve Sluggishly: A Simplification of the Dynamics and a Reconciliation with the Absorption Approach

6.1 Introduction

6.2 An extended version of a Mundell-Fleming model and the current account

6.3 A reconciliation with the absorption approach

6.4 A phase diagram analysis of the saddle path: an illustration

6.5 Concluding remarks

7 Growth and the Balance of Payments under Alternative Exchange Rate Regimes: The Case of a Small Economy

7.1 Introduction

7.2 A growth model of an open economy with capital immobility and fixed exchange rates

7.3 A growth model of an open economy with perfect capital mobility and fixed exchange rates

7.4 A growth model of an open economy with perfect capital mobility and flexible exchange rates

7.5 Secular and cyclical movements in the balance of payments 
7.6 Seigniorage and the foreign exchange regime

8 Economic Stability under Fixed, Flexible and Managed Exchange Rates

$\begin{array}{ll}8.1 \text { Introduction } & 160\end{array}$

8.2 A symmetric two-country model 161

8.3 The solution of the exchange rate under pure floating 170

8.4 Solving the model under alternative exchange rate regimes 172

8.5 Reporting and commenting on results 176

$\begin{array}{ll}8.6 \text { Concluding remarks } & 181\end{array}$

9 International Interdependence and Macroeconomic Policy

Coordination (by Frederick van der Ploeg)

9.1 Introduction 183

9.2 Monetary interdependence under floating exchange rates $\quad 187$

9.3 International policy coordination under floating exchange rates

9.4 Managed exchange rates

9.5 Interpretation of results and comparison with monetary union 198

9.6 Can international policy coordination be counterproductive? 200

9.7 Rational expectations and wage-price dynamics 205

9.8 Idiosyncratic supply shocks and the case for monetary union 208

9.9 Concluding remarks 213

10 Monetary and Portfolio Balance Models: Which does the Empirical Evidence Support? (by Ronald MacDonald) 217

$\begin{array}{ll}10.1 \text { Introduction } & 217\end{array}$

10.2 Uncovered and risk-adjusted uncovered interest rate parity 219

10.3 Evidence for a risk premium from the literature on the optimality of the forward rate as a predictor of the future exchange rate

10.4 Reduced-form exchange rate modelling: some in-sample and out-of-sample evidence

10.5 The out-of-sample forecasting performance of asset approach reduced forms

10.6 Explanations for the poor performance of asset approach reduced forms

10.7 Tests of forward looking monetary and portfolio balance models

10.8 Purchasing power parity: a review of the recent evidence

10.9 Concluding remarks 


\section{List of Tables and Figures}

\section{Tables}

8.1 Asymptotic variances under fixed exchange rates

8.2 Asymptotic variances under pure float

8.3 Asymptotic variances under managed floating: insulating aggregate demand from the real exchange rate without requiring a fixed real exchange rate

8.4 Asymptotic variances under managed floating: the Miller-Williamson proposals of fixing the real exchange rate

9.1 Policy responses to a common adverse supply shock under alternative exchange-rate regimes

9.2 Effects of an idiosyncratic adverse supply shock under alternative exchange-rate regimes

9.3 Policy responses to an idiosyncratic adverse supply shock under alternative exchange-rate regimes

\section{Figures}

1.1a A stable foreign exchange market

1.1b A stable foreign exchange market

1.1c An unstable foreign exchange market

1.2 Balance of payments adjustments to a devaluation when resources are underemployed: the absorption approach

1.3 Adjustments to a devaluation at full employment 18

1.4 Policies for internal and external balance 19

1.5 Internal balance, external balance and the real exchange rate 22

1.6 The path of output, of domestic prices and of the nominal exchange rate

1.7 Balance of payments adjustments to a devaluation: the monetary approach 
2.1a A permanent and unanticipated increase in $m_{d}$

2.1b A permanent and unanticipated increase in $\left(\pi-\pi^{*}\right) \quad 38$

2.2 Deriving the perfect foresight path

2.3 Adjustments in the real exchange rate and in relative liquidity to monetary disturbances

2.4a A permanent and unanticipated increase in $m_{d}$ : adjustments in $e$ and in $p_{d}$ when prices are sticky and when prices are flexible

2.4b An unanticipated increase in $\left(\pi-\pi^{*}\right)$ : adjustments in $e$ and in $p_{d}$ when prices are sticky and when prices are flexible

2.5 Adjustments to unanticipated monetary disturbances

2.6 Adjustments to monetary disturbances: a case of undershooting

2.7a Exchange rate adjustments in a sticky-price, underemployment model - a case of overshooting: $k \delta+\psi \gamma-1<0$

2.7b Exchange rate adjustments in a sticky-price, underemployment model - a case of undershooting: $k \delta+\psi \gamma-1>0$

3.1a Portfolio balance loci in $\left(\left(r_{b}\right)^{*}, E\right)$ space

3.1b Portfolio balance responses to a rise in $F$

3.1c Portfolio balance responses to a rise in $M$

3.1d Portfolio balance responses to a rise in $B$ : the case where foreign and domestic bonds are (relatively) close substitutes

3.1e Portfolio balance responses to an open-market increase in $M$ in exchange for $\mathrm{B}(d M+d B=0)$

3.1f Portfolio balance responses to an open-market increase in $F$ in exchange for $B(d B+E d F=0)$

3.1g Portfolio balance responses to an increase in the expected rate of depreciation of the exchange rate when bonds are 'close' substitutes

3.2 Portfolio balance and the exchange rate in a single-bond world

3.3 The current account and the exchange rate under rational expectations: deriving the saddle path

3.4 The current account and the exchange rate under rational expectations: responses to an unanticipated open-market purchase of domestic bonds for money

3.5a Current account and exchange rate responses (under rational expectations) to an unanticipated open-market purchase of domestic bonds for foreign bonds: the 'close' substitutes case

3.5b Current account and exchange rate responses (under rational expectations) to an unanticipated open-market purchase of domestic bonds for foreign bonds: the 'poor' substitutes case

4.1 Short-run equilibrium in the markets for goods and assets

4.2-6 Impact, dynamic and steady-state adjustments under static expectations: the current account and the real exchange rate

4.7a The nominal exchange rate and the current account under static expectations: adjustments to an open-market operation

4.7b The nominal exchange rate and the current account under static expectations: adjustments to an increase in export demand 
4.8a The nominal exchange rate and the current account under rational expectations: deriving the saddle path

4.8b The nominal exchange rate and the level of foreign assets: steady-state adjustments to open-market operations

4.8c The nominal exchange rate and the level of foreign assets: steady-state adjustments to an increase in export demand

4.8d The nominal exchange rate and the level of foreign assets: impact and dynamic adjustments to open-market operations under perfect foresight

4.8e The nominal exchange rate and the level of foreign assets: impact and dynamic adjustments to an increase in export demand under perfect foresight

5.1 IS-LM adjustments in $(i, y)$ space: the stable cases considered $\quad 114$

5.2 Phase diagrams in $(c, \ell)$ space

5.3 Adjustments in competitiveness and liquidity to an unanticipated reduction in $\mu$

$5.4 \mathrm{a}$ The paths of money and prices

$5.4 \mathrm{~b}$ The path of output

5.5a The paths of money and prices in a model of non-sterilised intervention

5.5b The path of output in a model of non-sterilised intervention

6.1 The joint determination of $F$ and $c$ across steady states: adjustments to a reduction in $\mu$ when $\lambda \mu>1$, and to an increase in $\phi$

6.2 The joint determination of $F$ and $c$ across steady states: adjustments to an increase in foreign income when $\sigma / f=v / \delta$

6.3 Adjustments across steady states to a shift in preferences towards the foreign good at the expence of the domestic good

6.4 The characteristics of the stable path of $\ell, F$ and $c$ associated with an unanticipated pure fiscal expansion

6.5a The path of inflation

6.5b The path of output

6.6a The time path of the real exchange rate 142

6.6b The time path of the real interest rate 142

7.1 Growth, the balance of payments and capital immobility 152

7.2 Growth, the balance of payments and capital mobility 154

$\begin{array}{ll}\text { 9.1 The two-country Mundell-Fleming model } & 189\end{array}$

$\begin{array}{ll}\text { 9.2 Reaction functions under managed exchange rates } & 197\end{array}$ 


\section{Acknowledgements}

Emmanuel Pikoulakis wishes to express his gratitude for the invaluable support provided by his publisher, Mr Stephen Rutt, throughout this project, and also to Mr Keith Povey for the high quality and promptness of his editorial services.

The author and publishers are grateful to the following for permission to reproduce extracts from: Private Behaviour and Government Policy in Interdependent Economics (1990), by permission of Oxford University Press and the Greek Economic Review; Problems of International Finance (1984) ed. J. Black and G.S. Dorrance, by permission of Macmillan Publishers; Exchange Rates and Open Economy Economics (1989) ed. M. Taylor and Ronald MacDonald, by permission of Blackwell Publishers; Papers from Proceedings volumes by permission of Tagung Geld, Banker and Versicherungen. Every effort has been made to trace all the copyright-holders, but if any have been inadvertently overlooked the publishers will be pleased to make the necessary arrangement at the first opportunity. 